\title{
PENGARUH NETWORKING CAPITAL , CASH FLOW dan GROWTH OPPORTUNITY TERHADAPRETURN ON ASSET (ROA) DI PERUSAHAAN TEKSTIL DAN GARMEN YANG TERDAFTAR DI BURSA EFEK INDONESIA
}

\author{
${ }^{1}$ Ayu Indriani, ${ }^{2}$ Heny Triastuti Kurnia Ningsih, ${ }^{3}$ Zenni Riana, ${ }^{4}$ Sri Elviani \\ ${ }_{1,2,3,4}$ Universitas Islam Sumatera Utara \\ 1ayuindriani039@gmail.com, ${ }^{2}$ henytriastuti@fe.uisu.ac.id, ${ }^{3}$ zenniriana@fe.uisu.ac.id, ${ }^{4}$ srielviani@fe.uisu.ac.id
}

\begin{abstract}
The purpose of this study was to determine whether Net Working Capital, Cash Flow and Growth Opportunity partially or simultaneously affect the Return On Asset (ROA) of the Textile and Garment Sub-Sector Companies listed on the IDX. Data collection techniques are using secondary data taken from Indonesia Stock Exchange website, Multiple Linear regression Analysis Technique, Hypothesis Test, namely $T$ Test and F Test, Determination Coefficient Test using the SPSS Version 20 application.The results of this study reveal that the Net Working Capital variable partially does not have a significant effect on Return On Asset, the Cash Flow variable partially has no significant effect on Return On Asset, and Growth Opportunity partially has a significant effect on Return On Assets, while the Net Working Capital variable has no significant effect on Return On Asset. Simultaneously, Cash Flow and Growth Opportunity have no effect on Return On Assets.
\end{abstract}

Keywords:Net Working Capital, Cash Flow. Growth Opportunity and Return On Asset.

ABSTRAK : Tujuan penelitian ini adalah untuk mengetahui apakah Net Working Capital, Cash Flow dan Growth Opportunity secara parsial maupun Simultan berpengaruh terhadap Return On Asset (ROA) pada Perusahaan Sub Sektor Tekstil dan Garmen yang terdaftar di BEI, Teknik pengumpulan data adalah menggunakan data sekunder yang diambil dari website Bursa Efek Indonesia, Teknik Analisis regresi Linier Berganda, Uji Hipotesis yaitu Uji $T$ dan Uji f, Uji Koefisien Determinasi menggunakan aplikasi SPSS Versi 20. Hasil dari penelitian ini mengungkapkan bahwa variabel Net Working Capital secara parsial tidak berpengaruh signifikan terhadap Return On Asset, Variabel Cash Flow secara parsial tidak berpengaruh signifikan terhadap Return On Asset, dan Growth Opportunity secara parsial berpengaruh signifikan terhadap Return On Asset, Sedangkan Variabel Net Working Capital, Cash Flow dan Growth Opportunity secara simuktan tidak berpengaruh terhadap Return On Asset.

Kata kunci: Net Working Capital, Cash Flow. GrowthOpportunity dan Return On Asset.

\section{Pendahuluan (Introduction)}

Persaingan bisnis tidak hanya terbatas dalam persaingan sesama perusahaan domestik, melainkan telah menjadi persaingan perusahaanperusahaan internasional, sehingga setiap perusahaan dituntut membuat rencana yang matang pada semua aspek perusahaan, tidak terkecuali yang berkaitan dengan kebijakan keuangan perusahaan. Karena, kepercayaan investor ataupun kreditur terletak pada bagaimana perusahaan mampu untuk menjaga tingkat liquiditas dan profitabilitas. Keberhasilan dan kegagalan suatu perusahaan dapat dilihat melalui kondisi keuangan perusahaan dengan informasi memadai yang terdapat di dalam laporan keuangan perusahaan. Informasi keuangan perusahaan ,merupakan salah satu kebutuhan penting bagi stakeholder suatu perusahaan terutama para investor. Kini, perusahaan memiliki investor yang tersebar dalam berbagai wilayah geografis, dimana para investor ini memerlukan berbagai informasi berkaitan dengan perusahaan sebagai pertimbangan dalam menanamkan modal mereka.Sub sektor textile dan garment termasuk kedalam bisnis yang dapat bertahan terhadap 
permasalahan yang pernah terjadi di Indonesia. Salah satunya adanya persaingan perusahaan textile dan garment untuk mengembangkan usahanya dengan meningkatkan kinerja keuangan. Kinerja keuangan memiliki peranan yang sangat penting dalam kegiatan usaha untuk mempertahankan kelangsungan hidup perushaan kedepannya.Sub sektor textile dan garment dinilai baik apabila mempunyai kinerja keuangan yang baik pula. Semakin baik kinerja keuangan perusahaan menunjukkan bahwa perusahaan stabil dan mampu mencapai tujuannya, yaitu memperoleh laba guna miningkatkan kesejahteraan stakeholders

Return On Asset (ROA) merupakan salah satu rasio profitabilitas yang dapat mengukur kemampuan perusahaan dalam menghasilkan laba dari aktiva yang digunakan. ROA mampu mengukur kemampuan perusahaan menghasilkan keuntungan pada masa lampau untuk kemudian diproyeksi dimasa yang akan datang. Return On Asset atau tingkat pengembalian asset merupakan indikator yang mengukur seberapa baik suatu perusahaan dalam memanfaatkan asset yang dimilikinya untuk menghasilkan laba. Net Working Capital adalah selisih antara aset lancar dengan kewajiban lancar di neraca. Pengukuran ini penting bagi manajemen perusahaan, vendor maupun kreditor umum karena Modal Kerja Bersih ini dapat menunjukkan likuiditas jangka pendek perusahaan serta kemampuan manajemen untuk menggunakan asetnya secara efisien. Cash flow merupakan arus kas atau aliran kas yang ada di perusahaan dalam periode tertentu.Tujuan utama dari pengelolaan kas adalah untuk mengetahui seberapa besar kemampuan perusahaan dalam menghasilkan kas. Growth opportunity adalah peluang pertumbuhan perusahaan di masa depan. Perusahaanperusahaan yang memiliki pertumbuhan yang cepat seringkali harus meningkatkan aktiva tetapnya.

\section{Landasan Teori (Literature Review)}

\subsection{ROA}

Berikut ini daftar perusahaan pada sub sektor Tetil dan Garment yang menjadi sampel pada penelitian, yaitu sebagai berikut :

Tabel 1. Sampel Peneliian

\begin{tabular}{|c|c|l|}
\hline No & Kode Perusahaan & \multicolumn{1}{c|}{ Nama Perusahaan } \\
\hline 1 & BELL & PT. Trisula Textile Indutries Tbk. \\
\hline 2 & ESTI & PT. Ever Shine Tex Tbk. \\
\hline
\end{tabular}

Menurut Brigham dan Houston (2010:148)' Return On Asset adalah rasio laba bersih terhadap total asset mengukur pengembalian atas total asset setelah bunga pajak.

\section{2. $N W C$}

Menurut kasmir (2012:182) bahwa perputaran modal kerja merupakan salah satu rasio untuk mengukursejauh mana modal kerja digunakan secara efektif.

\section{3. $\mathrm{CF}$}

Menurut Sofyan Syafri Harahap (2011:257) cash flow adalah arus masuk maupun arus keluar kas yang berdasarkan tiga laporan aktivitas perusahaan yaitu aktivitas pembiayaan, aktivitas operasi, dan aktivitas investasi.

\section{4. $G O$}

Growth opportunity adalah peluang pertumbuhan perusahaan di masa depan Mai dalam Hermuningsih,( $2013: 129)$.

\section{METODE PENELITIAN (METHOD/RESEARCH DESIGN) 3.1. Objek Penelitian}

Objek penelitian dalam penelitian pada perusahaan Textil dan Garment yang terdaftar di Bursa Efek Indonesia dengan variabel yang diteliti Net Working Capital (X1), Cash Flow (X2), Growth Opportunity (X3) dan Return On Asset (Y).

\subsection{Populasi Penelitian}

Populasi yang digunakan peneliti dalam penelitian ini adalah menggunakan perusahaann Textile dan Garment yang terdaftar di BEI. Adapun populasi dalam penelitian ini adalah sebanyak 18 perusahaan subsector Textile dan Garment yang terdaftar di Bursa Efek Indonesia periode 2017-2019.

\subsection{Sampel Penelitian}




\begin{tabular}{|c|c|l|}
\hline No & Kode Perusahaan & \multicolumn{1}{|c|}{ Nama Perusahaan } \\
\hline 3 & INDR & PT. Indo Rama Synthetic Tbk. \\
\hline 4 & RICY & PT. Ricky Putra Globalindo \\
\hline 5 & TFCO & PT. Tifico Fiber Indonesia Tbk. \\
\hline 6 & TRIS & PT. Trisula Internasional Tbk. \\
\hline 7 & ZONE & PT. Mega Perintis Tbk. \\
\hline
\end{tabular}

Sumber : Sahamok.com, (yang diolah 2021)

\subsection{Teknik Analisis Data}

\subsubsection{Analisis Data Statistik Deskriptif}

Ialah analisis yang dilakukan untuk menilai karakteristik dari sebuah data. Karakteristik yang dinilai antara lain : mean,median, sum, variance, standard error. Standard error of mean , mode, range atau rentang, minimal, maksimal, skewness dan kurtosis.

\section{Hasil Penelitian/Temuan (Findings) 4.1. Analisis Data Statistik Deskriptif}

Tabel 2. Hasil Uji Deskriptif

Descriptive Statistics

\begin{tabular}{|c|c|c|c|c|c|}
\hline & $\mathrm{N}$ & $\begin{array}{l}\text { Minimu } \\
\mathrm{m}\end{array}$ & Maximum & Mean & $\begin{array}{l}\text { Std. } \\
\text { Deviation }\end{array}$ \\
\hline NWC & 21 & 1577925 & $\begin{array}{l}13102025689 \\
59\end{array}$ & $\begin{array}{l}139673335917, \\
81\end{array}$ & $\begin{array}{l}28508445604 \\
1,960\end{array}$ \\
\hline $\mathrm{CF}$ & 21 & 1,385 & 683,222 & 136,55400 & 208,978003 \\
\hline GO & 21 &, 101 & 35,189 & 10,53671 & 9,503470 \\
\hline ROA & 21 &, 153 & 10,205 & 3,72605 & 3,129999 \\
\hline $\begin{array}{ll}\text { Valid } & \mathrm{N} \\
\text { (listwise) } & \end{array}$ & 21 & & & & \\
\hline
\end{tabular}

Sumber : SPSS Versi 20

Berdasarkan tabel 5.1 dapat dilihat bahwa nilai rata-rata dari Return On Asset (Y) yang dilakukan oleh 7 perusahaan Tekstil dan Garment yang terdaftar di Bursa Efek Indonesia (BEI) selama tahun 2017-2019 adalah 3,72605. Dengan nilai minimumnya 0,153 dan nilai maksimumnya 10,205, sedangkan untuk standar devisiasinya adalah sebesar 3,129999. Hal ini menunjukkan bahwa Return On Asset tersebut sangat bervariasi dan berfluktuatif tajam selama periode pengamatan.

1) Variabel bebas yang pertama yaitu Net Working Capital yang memperlihatkan ratarata adalah 139673335917,81. Dengan nilai minimum 1577925 dan nilai maksimum 1310202568959 sedangkan standar devisiasinya adalah 285084456041,960. Perbedaan nilai minimum dan maksimum yang cukup jauh pada Net Working Capital ini dapat disebabkan oleh likuiditas jangka pendek perusahaan serta kemampuan manajemen untuk menggunakan asetnya secra efisien.

2) Variabel bebas kedua, yaitu Cash Flow yang memperlihatkan nilai rata-rata 136,55400 . Dengan nilai minimumnya 1,385 dan nilai maksimumnya 683,222. Sedangkan standar devisiasinya adalah 208,978003. Dari hasil tersebut dapat dilihat bahwa nilai maksimumnya yang diperoleh cukup tinggi. Angka tersebut menunjukkan bahwa perusahaan mempunyai tingkat aliran kas yang cukup baik.

3) Variabel ketiga, yaitu Growth Opportunity yang memperlihatkan nilai rata-ratanya adalah 10,53671. Dengan nilai minimumnya 0,101 dan nilai maksimumnya 35,189 . Sedangkan standar devisiasinya adalah 9,503470. Perbedaan nilai minimum dan maksimumnya yang cukup juh pada Growth Opportunity ini 
dapat disebabkan oleh semakin tinggi tingkat pertumbuhan suatu perusahaan akan semakin besar tingkat kebutuhan dana untuk membiayai ekspansi.

Tabel 3. Hasil Uji Kolmogorov-Smirnov

One-Sample Kolmogorov-Smirnov Test

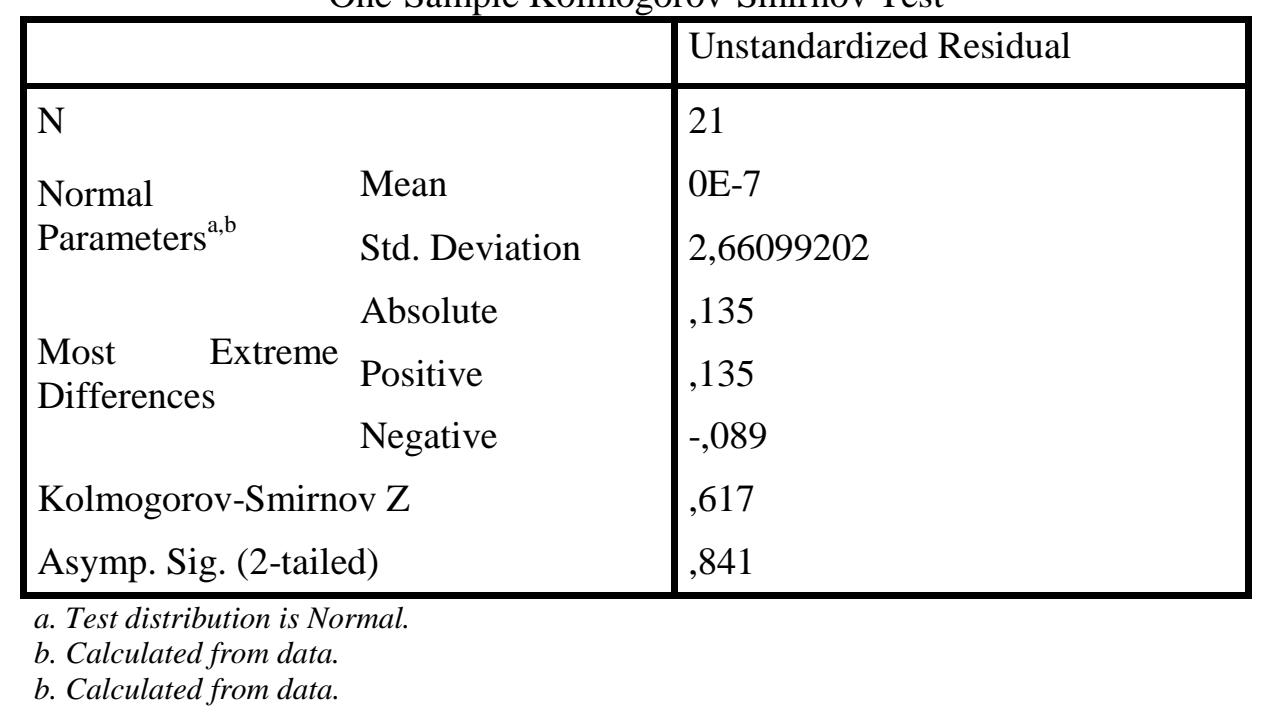

Tabel 2. menunjukkan hasil uji Normalitas untuk data yang dianalisis. Uji Normalitas dengan menguji normalitas residual dan dapat dilihat melalui Asymp. Sig (2-tailed) sebesar

\subsection{Uji Asumsi Klasik \\ 4.2.1. Uji Normalitas}

0,841 jauh di atas nilai signifikan 0,05 sehingga, dapat disimpulkan bahwa model regresi terdistribusi secara normal.

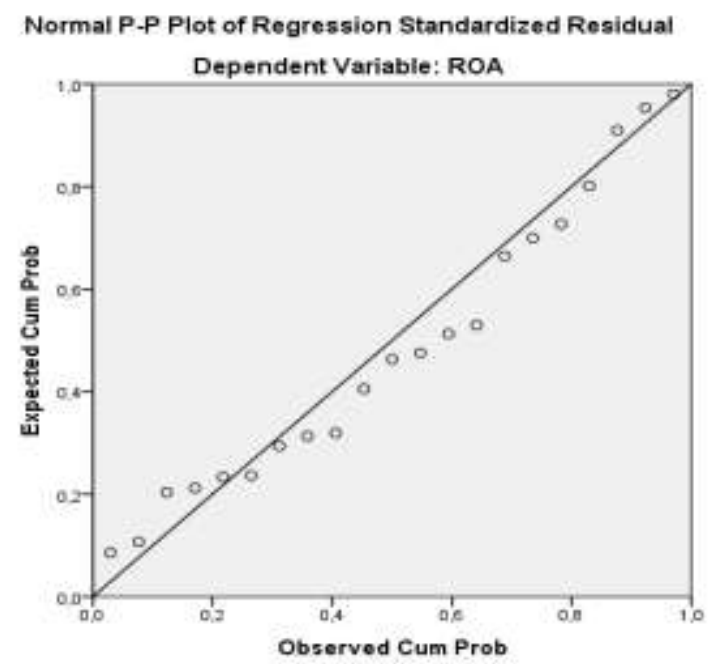

Gambar 1 Garafik P - Plot

Sedangkan pada gambar 1 grafik normal PPlot didapatkan pola distribusi dengan titik-titik menyebar berhimpit di sekitar diagonal dan kedua hal ini menunjukkan bahwa residual terdistribusi secara normal.

\subsubsection{Uji Multikolinearitas}


Tabel 4. Hasil Uji Mutikolinearitas Coefficients $^{\mathrm{a}}$

\begin{tabular}{|c|c|c|c|c|c|c|c|}
\hline \multirow[t]{2}{*}{ Model } & \multicolumn{2}{|c|}{$\begin{array}{l}\text { Unstandardized } \\
\text { Coefficients }\end{array}$} & $\begin{array}{l}\text { Standardized } \\
\text { Coefficients }\end{array}$ & \multirow[t]{2}{*}{$\mathrm{t}$} & \multirow[t]{2}{*}{ Sig. } & \multicolumn{2}{|l|}{$\begin{array}{l}\text { Collinearity } \\
\text { Statistics }\end{array}$} \\
\hline & $\mathrm{B}$ & Std. Error & Beta & & & Tolerance & VIF \\
\hline (Constant) & 1,719 & 1,335 & & 1,288 & ,215 & & \\
\hline NWC & $-1,288 \mathrm{E}-012$ &, 000 &,- 117 &,- 544 & ,593 & ,915 & 1,093 \\
\hline $\mathrm{CF}$ &, 002 & ,003 & , 150 & ,642 & ,529 &, 782 & 1,278 \\
\hline GO & , 178 &, 074 & ,542 & 2,415 & ,027 &, 844 & 1,184 \\
\hline
\end{tabular}

a. Dependent Variable: ROA

Hasil perhitungan nilai Tolerence dan VIF dapat dilihat bahwa semua variabel yang digunakan dalam penelitian ini memiliki nilai tolerence yang lebih besar dari 0,10 dan VIF yang kurang dari 10,00. Hal ini berarti bahwa,tidak ada gejala multikolinearitas antar seluruh variabel independen.

\subsubsection{Uji Heteroskedastisitas}

Scatterplot

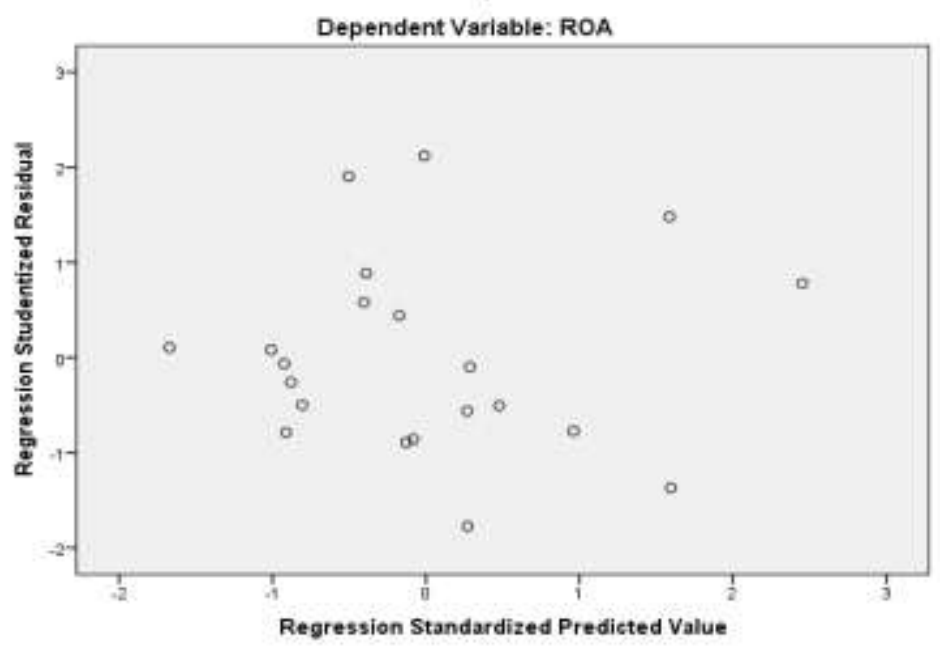

Gambar 2. Scatter Ploy

Grafik scatterploy menunjukkan tidak ada pola yang jelas dan titik-titik menyebar di atas dan dibawag angka 0 pada sumbu Y. Hal ini dapat disimpulkan bahwa tidak terjadi heteroskedastisitas pada model regresi.

\section{Analisis Regresi Linear Berganda}

Tabel 5. Hasil Analisis Regresi

Coefficients $^{\mathrm{a}}$

\begin{tabular}{|c|c|c|c|c|c|c|}
\hline \multirow[t]{2}{*}{$\overline{\text { Mod }}$} & & \multicolumn{2}{|l|}{$\begin{array}{l}\text { Unstandardized } \\
\text { Coefficients }\end{array}$} & \multirow{2}{*}{$\begin{array}{l}\text { Standardized } \\
\text { Coefficients } \\
\text { Beta }\end{array}$} & \multirow[t]{2}{*}{$\mathrm{t}$} & \multirow[t]{2}{*}{ Sig. } \\
\hline & & $\mathrm{B}$ & Std. Error & & & \\
\hline \multirow{4}{*}{1} & (Constant) & 1,719 & 1,335 & & 1,288 & 215 \\
\hline & NWC & $-1,288 \mathrm{E}-012$ & ,000 &,- 117 &,- 544 & ,593 \\
\hline & $\mathrm{CF}$ & ,002 & ,003 & , 150 & ,642 & ,529 \\
\hline & GO & 178, & ,074 & 542, & 2,415 & 027 \\
\hline
\end{tabular}


Hasil pengujian dengan metode regresi linier berganda di atas, Return On Asset (ROA) memiliki konstanta sebesar 1,719.
5.1. Uji hipotesis

5.1.1. Uji T (UJi Signifikan Parsial )

Tabel 6. Hasil Uji T

Coefficients $^{\mathrm{a}}$

\begin{tabular}{|c|c|c|c|c|c|c|c|c|}
\hline & \multirow[t]{2}{*}{ Model } & \multicolumn{2}{|c|}{$\begin{array}{c}\text { Unstandardized } \\
\text { Coefficients }\end{array}$} & \multirow{2}{*}{$\begin{array}{c}\begin{array}{c}\text { Standardized } \\
\text { Coefficients }\end{array} \\
\text { Beta }\end{array}$} & \multirow[t]{2}{*}{$\mathrm{t}$} & \multirow[t]{2}{*}{ Sig. } & \multicolumn{2}{|c|}{ Collinearity Statistics } \\
\hline & & $\mathrm{B}$ & Std. Error & & & & Tolerance & VIF \\
\hline \multirow{4}{*}{1} & (Constant) & 1,719 & 1,335 & & 1,288 & ,215 & & \\
\hline & NWC & $-1,288 \mathrm{E}-012$ &, 000 &,- 117 &,- 544 &, 593 & ,915 & 1,093 \\
\hline & $\mathrm{CF}$ &, 002 &, 003 &, 150 & ,642 &, 529 & ,782 & 1,278 \\
\hline & $\mathrm{GO}$ & , 178 & ,074 & ,542 & 2,415 & ,027 & ,844 & 1,184 \\
\hline
\end{tabular}

a) Net Working Capital memiliki signifikan sebesar 0,593> taraf signifikan 0,05 dengan nilai $\quad t_{\text {hitung }}<t_{\text {tabel }} \quad(0,5442<2,10982)$. Berdasarkan hasil uji hipotesis menunjukkan bahwa Net Working Capital tidak berpengaruh signifikan terhadap Return On Asset. Dan menolak H1 yang menyatakan bahwa Net Working Capital berpengaruh signifikan terhadap Return On Asset.

b) Cash Flow memiliki nilai signifikan 0,529> taraf signifikan 0,05 dengan nilai $\mathrm{t}_{\text {hitung }}<\mathrm{t}_{\text {tabel }}$ $(0,642<2,10982)$. Berdasarkan hasil uji hipotesis menunjukkan bahwa Cash Flow tidak berpengaruh signifikan terhadap Return
On Asset. Dan menolak H2 yang menyatakan bahwa Cash Flow berpengaruh signifikan terhadap Return On Asset.

c) Growth Opportunity memiliki signifikan sebesar 0,027 > taraf signifikan 0,05 dengan nilai $t_{\text {hitung }}>t_{\text {tabel }}(2,415>2,10982)$. Berdasarkan hasil uji hipotesis menunjukkan bahwa Growth Opportunity berpengaruh signifikan terhadap Return On Asset. Dan menerima $\mathrm{H} 3$ yang menyatakan bahwa Growth Opportunity berpengaruh signifikan terhadap Return On Asset.

\subsubsection{Uji F (Simultan)}

Tabel 7. Hasil Uji F

ANOVA $^{\mathrm{a}}$

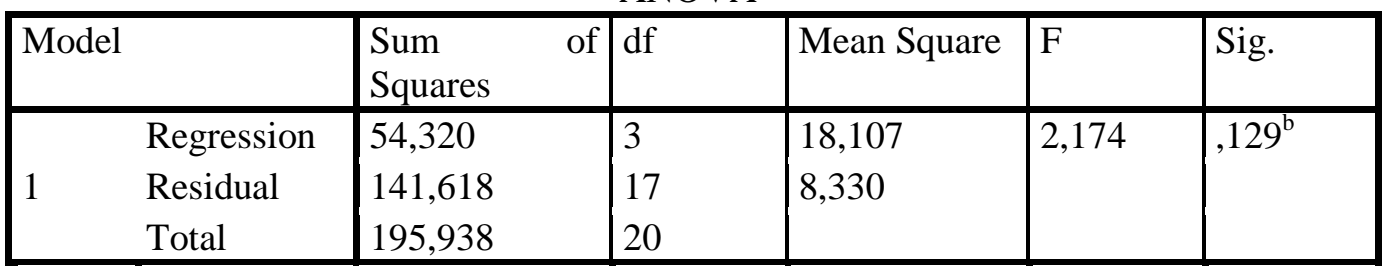

a. Dependent Variable: ROA

b. Predictors: (Constant), GO, NWC, CF

Tabel 7. menunjukkan nilai $f_{\text {hitung }}$ sebesar 2,174 dengan tingkat signifikansi 0,05. Dapat dilihat pada tabel statistic pada tingkat signifikansi 0,05 dengan $\mathrm{df} 1=2$ dan $\mathrm{df} 2=18$, maka diperoleh hasil untuk $f_{\text {tabel }}$ sebesar 3,55. Berdasarkan hasil tersebut, $\mathrm{f}_{\text {hitung }}$ lebih kecil dari $f_{\text {tabel }}(2,174<3,55)$. Berdasarkan signifikansi, dapat dilihat bahwa nilai signifikansi pada uji $\mathrm{f}$ sebesar 0,005. Hal ini berarti nilai signifikansi pada uji $f$ kurang dari $0,05 \quad(0,005<0,05)$. Berdasarkan hasil uji $f$ dalam penelitian ini dinyatakan baahwa model regresi tersebut tidak signifikan secara simultan. Jadi, dapat disimpulkan bahwa variabel independen (Net Workig Capital, Cash Flow dan Growth Opportunity) secara bersama-sama tidak berpengaruh signifikan terhadap Return On Asset. 


\subsubsection{Uji Koefisien Determinasi}

Tabel 8. Hasil Analisis Koefisien Determinasi Model Summary ${ }^{\mathrm{b}}$

\begin{tabular}{|l|l|l|l|l|}
\hline Model & $\mathrm{R}$ & $\mathrm{R}$ Square & $\begin{array}{l}\text { Adjusted } \\
\text { Square }\end{array}$ & $\begin{array}{l}\mathrm{R} \\
\text { Std. Error of the } \\
\text { Estimate }\end{array}$ \\
\hline 1 &, $527^{\mathrm{a}}$ &, 277 &, 150 & 2,88625 \\
\hline
\end{tabular}
a. Predictors: (Constant), GO, NWC, CF
b. Dependent Variable: $R O A$.

Dari tabel 8. dapat dilihat bahwa nilai koefisien determinasi (Adjusted $\mathrm{R}^{2}$ ) yang diperoleh sebesar 0,150 atau sebesar 15\%. Hal ini menunjukkan Net WorkingCapital, Cash Flow dan Growth Opportunity hanya berkontribusi sebesar 15\% terhadap pembagian Return On Asset sedangkan sebesar $85 \%$ dipengaruhi oleh variabel lain yang tidak diteliti dalam penelitian ini.

\section{Kesimpulan}

1) Net Working Capital tidak berpengaruh signifikan terhadap Return On Asset, yang berarti bahwa tinggi rendahnya modal kerja tidak berpengaruh terhadap kemampuan perusahaan dalam hal memperoleh laba dari aktiva yang digunakan pada perusahaan tektil dan garmen yang terdaftar di Bursa Efek Indonesia (BEI) 2017-2019

2) Cash Flow tidak berpengaruh signifikan terhadap Return On Asset, yang berarti tinggi atau rendahnya arus kas tidak berpengaruh pada perolehan laba dari aktiva yang digunakan pada beberapa perusahaan tekstil dan garmen yang terdaftar di Bursa Efek indonesia (BEI) 2017-2019.

3) Growth Opportunity berperngaruh signifikan terhadap Return on Asset, yang berarti bahwa ssemakin tinggi peluang pertumbuhan perusahaan maka tinggi pula perolehan laba pada beberapa perusahaan tekstil dan garment yang terdaftar di Bursa Efek Indonesia (BEI) 2017-2019.

4) Net Working capital, Cash Flow dan Growth Opportunity secara bersamaan tidak berpengauh signifikan tehadap Return On Asset (ROA) pada perusahaan Tektil dan garment yang terdaftar di bursa Efek Indonesia (BEI) 2017-2019.

\section{DAFTAR PUSTAKA}

Brigham Eugene dan Houston Joel. (2010). Dasar-dasar Manajemen Keuangan (Edisi 11). Salemba Empat.

Herlina Yesi. (2012). Pengaruh Current Ratio, Net Working Capital Turnover dan Debt to Asset Ratio terhadap ROA pada perusahaan Property dan Real Estate yang terdaftar di Bursa Efek Indonesia Periode 2008-2012.

Hermuningsih1, S (2013). Pengaruh Profitabilitas, Growth Opportunity, Struktur Modal Terhadap Nilai Perusahaan Pada Perusahaan Publik di Indonesia. Buletin Ekonomi Moneter dan Perbankan, Oktober 2013,3-22.

Iskandar dkk. (2016). statistik Ekonomi (Edisi 1). Perdana Publishing.

Kasmir. (2012). Analisis Laporan Keungan (Edisi Revi). Rajawali Pers.

Rahayu, S. R. I., Nusantara, U., Guru, P., Indonesia, R., \& Kediri, U. N. P. (2016). PENGARUH CURRENT RATIO , NET WORKING CAPITAL TURNOVER , DAN DEBT TO ASSET RATIO TERHADAP ROA PADA PERUSAHAAN PROPERTY DAN REAL ESTATE YANG TERDAFTAR DI BURSA EFEK INDONESIA PERIODE 2012-2014.

Sapitri, P. (2016). Pengaruh Net Working Capital, Board Size, Growth Opportunity dan Cash Conversion Cycle Terhadap Cash Holding. June.

Saraswati, Y. F. (2014). PENGARUH GROWTH OPPORTUNITY DAN LEVERAGE TERHADAP NILAI PERUSAHAAN DENGAN PROFITABILITAS SEBAGAI VARIABEL INTERVENING ( Studi pada Perusahaan Consumer Goods yang Terdaftar di Bursa Efek Indonesia Periode 
2011-2014 ). 1-23.

Sartono Agus. (2010). Manajemen Keuangan

Teori dan Aplikasi (Edisi Keem). BPFE.

Sofyan Syafri Harahap. (2011). Analisis Kritis Atas Laporan Keuangan. PT. Raja
Grafindo Persada.

Supatmin. (2017). Jurnal mandiri : PENGARUH NET WORKING CAPITAL DAN CURRENT RATIO TERHADAP RETURN ON ASSETS. 1(2), 128-144. 